\title{
On the Interests of Non-human Animals in Traditional Yorùbá Culture: A Critique of Ọ̀rúnmì̀̀
}

\author{
Ofuasia, Emmanuel \\ Doctoral Fellow, Department of Philosophy, \\ Lagos State University, \\ Lagos, Nigeria. \\ Email: ofuasia.emma@yahoo.com
}

\begin{abstract}
Traditional Yorùbá culture admits the hegemonic locus that humans rank above all else on the planet. The outlook received decisive ratification several millennia ago in one of the Odùs of their Ifá Corpus. Specifically, in Odù Ògúndá Otura, one of the numerous chapters of the Ifá Corpus, Òrúnmilà, the founder and primordial deity of Ifá discloses his authorization, the use of non-human animals for sacrifice and other human ends interminably. In this study, we engage the Ifá chapter that upholds this outlook. We riposte that the age long supercilious perspective among the Yorùbá that humans rank higher and over non-human animals, as documented in the said Odù is no longer tenable on biological and moral-legal grounds. If the biological and moral-legal thrusts are not invalid, what framework is plausible when the interest(s) of non-human animals clash with the interest(s) of Ifá tradition and Yorùbá culture? On what basis will it be appropriate to jettison the interest(s) of the one for the interest(s) of the other? In the light of these posers, we employ Kai Horsthemke's ethical individualism as the suitable groundwork that considers the interest of animals recommended for sacrifice in Ifá obeisance.
\end{abstract}

Keywords: Ifá, Non-Human Animals, Òrúnmilà, Biological Sciences, Moral Philosophy.

Introduction: It is interesting to begin with the truth that moral discourse(s) centered on the status of non-human animals, regardless of situation and place will sometimes, divulge "...the conflict between the interests of animals and people's interests in culture." Incidentally, this inquiry attempts to unravel the conflict between the Yorùbá interest in Ifá propriety and tradition on the one hand and the interests of non-human animals in same culture on the other hand. The conflict or contradiction between these two spheres of understanding should not be perceived as a sign of failure. In other words when "in formal logic, contradiction is the signal of a defeat: but in the evolution of real knowledge it marks the first step in progress towards a victory." "When Ifá is consulted and animal sacrifice is recommended this is seen by the Yorùbá to be normal and in tune with the tradition and customs of the land. However, this interest in culture is now confronted by developments and advancements in the academia that non-human animals too have "interests that should not be cavalierly 
frustrated."3 A contradiction therefore ensues: Oughtn't we sacrifice the interest of the one for the other? On what grounds can the people's interests in culture be sustained in the face of the conflict with the interests of non-human animals? Are we to let it pass and place the one arbitrarily over the other? In this regard, Alfred N. Whitehead instructs: "We should wait: but we should not wait passively, or in despair. The clash is a sign that there are wider truths and finer perspectives within which a reconciliation of a deeper religion and a more subtle science will be found." 4 This is the core of this inquiry.

In what follows, an effort will be made to argue that the justification for the killing of non-human animals in Ifá and other variants of Oriṣà propriety founders on biological and moral-legal bases. For the fulfillment of its objective, the study has five parts, including this introduction. In the succeeding part, the case for the justification of non-human animals for human use and their surbordination to human beings as validated by Òrúnmilà in Odù Ògúndá Otura (one of the chapters of the Ifá corpus) is uncovered. But before this, an attempt will be made to provide an introductory but terse analysis of what Ifá connotes and does not. In the third section, the biological and moral-legal arguments that render Odù Ògúndá Otura antediluvian are comprehensively disclosed. In the fourth part, we propose a plausible framework to unknot the quagmire between the Yorùbá interest in Ifá tradition and status of nonhuman animals that had been deemed as nothing but entities fit only for human ends. The fifth part concludes this intellectual drudgery.

Ifá and Orúnmilà: The Justification for the Killing of Non-Human Animals for Human Ends: It is imperious to state from the outset that attempts to give a univocal definition to Ifá have not yielded results. There are as much understanding of the concept as there are scholars and practitioners of Ifá. For E.M. Lijadu, Ifá is "the word of divination which issues from the mouth of Orúnmilà." 5 In a related development, William Bascom puts that "the word Ifá is used to mean both the system of divination and the deity who controls it; and this deity is known also as Orúnmilà."6 Similarly, Nicholaj De Mattos Frisvold who is a practicing babaláwo appends:

"Ifá is a philosophy, a theogony, theology and cosmology rooted in a particular metaphysic that concerns itself with the real and ideal, the world and its beginning. It is rooted in the constitution of man the purpose of life and naure of fate. Ifá is a philosophy of character. The philosophy of Ifá lies at the root of any religious cult organization involving the veneration of Òris̀a. ${ }^{7}$

From the Frisvold's position, it seems the portrayal of Ifá as a philosophy of character has been the notable attitude advocated by many babaláwo (i.e. male Ifá practitioner) and iyanifá (i.e. female Ifá practitioner). Hence, it does not come as a surprise that even Nicholaj De Mattos Frisvold, being a babaláwo is not excluded from the trend. And this idea that Ifá passes muster as a philosophy of character is one of the 
fundamental truths embedded in some of the verses in Odù Ogbè-Yọnú (another Ifá

chapter) which is rendered in the English Nothing comes from getting angry

Patience is the father of character

An elder who has patience has everything.

This is why divination was casted for orí, and for character (iwà)

It is only cultivating character that is hard

There is not one bad ori in Ilé-Ife

It is a consequence of the foregoing Odì (a term for Ifá chapter) and similar ones that may have inspired Fayemi Ademola Kazeem to assess the ethico-sociological interpretation of Ifá as a paragon for building positive character and human personality in contemporary times. ${ }^{8}$ Hence, the perception that Ifá is a philosophy of character is not misplaced.

However, another crucial issue that needs to be addressed is the tendency to "use of Ifá and órúnmilä" to mean one and the same. For this reason, it is important to expatiate and expound further to see if we can deduce why this is the case. According to Kola Abimbola:

"Ifá, who lived for hundreds of years, and visited many parts of the world, bequeathed the Ifá divination system to humanity. Another name of Ifá is Orúnmilà. The word Ifá however, is used to refer to the Orisa (divinity) himself, his instruments of divination as well his system of divination and literature. The name òrúnmilà refers solely to the divinity himself... Ifá priests and priestesses were counselors, physicians, historians and philosophers of ancient Yorùbá land." 10
In this study, we shall admit and employ the perspective that Ifá includes a body of ancient, oral, Yorùbá poetic literature with metaphysical significance. But we are not the first to entertain this position. Several years ago, Ola Longe who endorses this locus chronicled that Ifá " $\ldots$ was originated and codified by Orúnmilà, who lived in İléİfẹe, several centuries ago." ${ }^{11}$ İlé-İ́ẹe, in present day Osun State, Nigeria is the cradle of Yorùbá civilization.

The Ifá corpus constitutes the storehouse of Yorùbá thought system. It is the ground of validation for Yorùbá cultural practices and social cohesion. Ifá corpus contains accounts of Yorùbá cosmology, of the founding of major Yorùbá towns and the relationship of deities with humans. ${ }^{12}$ Though records of Yorùbá lived experiences are found in Ifá, the corpus is not static. As a body of intellectual material, Ifá is simultaneously conservative and dynamic. Accounts recorded in Ifá chapters (Odù), provide us with explanations for certain practices in Yorùbá land. Ifá may be described as the compendium of Yorùbá life and practices. Ifá is composed of sixteen major chapters (Odù) and two hundred and forty derivatives, giving a total of two hundred 
and fifty-six chapters. ${ }^{13}$ And people consult these Odùs for diverse reasons.

But mainly, the reason why people consult Ifá is based on the assumption that the answers to what they seek can be provided by the divinity. Hence, it needs no elaboration that: "When people consult Ifá, they do so because they are convinced that Ifá has answers and that knowing those answers will enable them to solve, or at least make sense of, the problem or the circumstances that have led them to the babaláwo's door."14

One point to note is that for whatever the problem may be, solutions range within the recommendation to change behavior, make new life choices, make fruit offerings/rituals, and in most cases, use nonhuman animals for rituals. However, the use of non-human animals is indispensable especially during initiation into Ifá and other cults. We arrive at the boiling point!

The use of non-human animals for sacrifice was clearly articulated by Áwo Fáladé Òsúntólá in these words:

"But there's more to animal sacrifice than actively recharging an Orisa's cosmic ase-battery. Animal sacrifice also nourishes us with the meat thereby completing the cycle and affirming our connection to our earthly and heavenly egbe (community). Sacrificing an animal nourishes the spirits (with blood) and the community (with meat) thereby indexing the powerful link between humanity and the Orisa as they are both nourished by a single ritual process.
Offerings of fruit, amidu, and even drinks all recharge our Orisa's ase but they perform this task slowly and with coolness. Blood sacrifice, on the other hand, recharges an Orisa quickly and with heat." 15

The foregoing is a clear indication that animal sacrifice is a crucial aspect in Ifá tradition. Awó Fáladé Òsúntólá maintains that unless animal sacrifice is performed for initiation, such an initiation is not authentic. In his words:

"It is - in part - the intensity and "heat" produced from animal sacrifice that makes animal sacrifice mandatory in all Orisa and Ifa initiations. Simply put, if you were initiated without the act of animal sacrifice your Orisa was not fully birthed and by now your Orisa has dissolved back to the earth from which it came. Blood is not just symbolic of "birthing," the intensity of blood sacrifice also has a practical purpose it charges - or electrifies - the struggling ase of a newly incarnated Orisa so that it may endure on earth."16

The above thrusts endorse the outlook that the use of non-human animals for food and sacrifice is commonplace not only in Ifá initiations but other cult initiations among the traditional Yorùbá. However, it needs to be asked: is there any endorsement in the Ifá corpus for animal sacrifice? In this regard, Odù Ògúndá Otura, which is replete with a justification for the use of animals for sacrifice and surbordination of animals to humans, by Òrúnmilà will now be explored. A fair rendition in the English Language is simplified thus: 
Òrúnmilà said: "It is a matter of running helter-skelter"

Ifá says "It is a matter of being troubled"
The children of the rat were running helterskelter

They were troubled

I asked why they were running helter-skelter and troubled

The children of the rat said: "It was because of children"

Òrúnmilà asked them: "would you be my devotee?"

"What are we asking for?" The rat answered

"What is baba akeyo (the great teacher) saying"

But Òrúnmilà declared that the children of the rat may reproduce

They divined and provided solutions to the children of the rat

The children of the rat started having children

Two points are imperative for the embellishment of the main thrust of Ògúndá Otura, in the fore rendered Ifá chapter.

Firstly, by using the phrase 'children of the rat', one is tempted to counter that if the rat already has children why it be troubled? But hermeneutically speaking, the phrase is merely representative of the rat species.

The second point relates to the antecedent factors that informed the interchange. Òrúnmilà had come from the celestial realm, touring all the terrestrial species, when they were having challenges. In each of the places he toured, he discerned serious travails. He therefore asked what their problems were. The first place, which was the house of the rat (cited above), Òrúnmilà learned that the problem was due to lack of children. Ọrúnmilà demanded the rat species be devoted to him, to which they showed reluctance. In order words, the rats were not ready to lose anything in exchange for the good things they wanted from Olódùmarè, (the Higher God/Supreme Diety) through Orúnmilà. This is evident in their question: "What is baba akeyo (the great teacher) saying?" The rat species was pondering over the lack of tandem between being devoted to Órúnmilà on the one hand and the present agony and dilemma of childlessness, on the other hand.

Nevertheless, Òrúnmilà declared that they have children and it was so. Òrúnmilà repeated the same feat in the house of the fish, and all other animals until he encountered Homo sapiens. Òrúnmilà asked them the same question. Meanwhile humans benefitted from the advice of $\grave{E} s \grave{u}$, another primordial divinity (that is, òrì̀à in traditional Yorùbá theology) who had secretly told them to affirm devotion toward Orúnmilà. In addition, Òrúnmilà granted them too, the ability to multiply.

Sixteen years later, Òrúnmilà returned to check if they were doing well. One after the other he visited he abode of each animal species. He entered the house of the rat. The multitude of children did not even know him. They did not remember it was he who made it possible for them to multiply. They were even spitting at him. The same 
happened in the house of the fish, and other animals. The birds even defecated on him. However, when Òrúnmilà approached the house of humans, they recognized him from afar, ushered him in to be offered drinks and food. They provided him a place to sleep and he dwelt with them.

Consequently, Òrúnmilà who had hitherto been offended by the actions of the children of rat, fish, and other animals, prayed for humans and decreed that all those who revolted against humans shall henceforth be used as the exchange, substitute, buy back (i.e. irari) for the problems that manifest in human lives. In his pronouncement Òrúnmilà harps: "They will be irarí that is, 'a buy-back' for you and your children till eternity." This is the final verdict in Odù Ogúndá Otura which both debunks the vantage that non-human animals and humans are partners and fellow occupants of the planet. Secondly, it simultaneously serves as a thrust for their use as food and sacrifice, a perspective upheld by Áwo Fáladé Òsúntólá in a foregoing excerpt. Undoubtedly, Odù Ògúndá Otura contains the instance where humans conceded and accepted this hegemony. Being the devotee of Orúnmilà, they chorused thus:

What then would be the buyback of a devotee?

The children of the rat are the buy-back of a devotee The children of the rat What then would be the buyback of the devotee? The children of the fish are the buy-back of the devotee
The children of the fish What then would be the buyback of the devotee? The children of the bird are the buy-back of a devotee The children of the bird What then would be the buyback of a devotee? The children of animals are the buy-back of a devotee The children of animals

One does not need too much intellectual willpower to detect that Odù Ògúndá Otura endorses the use of non-human animals for rituals and sacrifice toward the amendment of human absurdities. Another point that must be amplified is that each of the species of fish, rat, and bird has significance that is not rendered explicit in the passage but demands a hermeneutic interpretation. Odù Òúndá Otura justifies the use of all animals that creep on land (symbolized by the rat species) for food and sacrifice. It endorses the use of all animals that fly (symbolized by bird species) for food and sacrifice. It also admits all animals that reside in water (symbolized by the fish species) for food and sacrifice. All these are calculated by the Odù to validate the locus that non-human animals are not perceived as beings with interests that must not be frustrated or sacrificed needlessly for human ends. This also contradicts the proposal that "the Yoruba recognize that animals have their own emotions, and that their pains are worthy of care consideration but not equal consideration with humans..." ${ }^{\prime 17}$ Clearly, the fore Odù sees animals as fit for human end 
as Immanuel $\mathrm{Kant}^{18}$ will come to admit several centuries later. Now that it has been established how non-human animals are used both as food and for rituals by Ifá injunction, it is now pertinent to examine the moral-legal and biological implications of Odù Ògúndá Otura.

\section{Òrúnmilà and the Status of Non-Human} Animals: Exposing the Biological and Moral-Legal Limitations: Orúnmilà's sanction that non-human animals are irari that is, 'a buy-back' for human problems for eternity, lacks moral cum legal justification on the one hand, but also vitiates the realities and truths about emergence and hierarchy of life as hold by the Biological Sciences on the other hand. But before exploring these perspectives, it is vital to reveal that the traditional Yorùbá had for several hundred years held an outlook that several philosophers in the academic history of the West will later admit. Aristotle, Immanuel Kant, St. Augustine for instance concluded as Órúnmilà did that the existence of other lives on the planet is sorely for the utility of humans. Whereas renowned and erudite persona such as Peter Singer ${ }^{19}$; Tom Regan ${ }^{20}$; Joel Feinberg ${ }^{21}$; Arthur Caplan ${ }^{22}$ and recently Rainer Ebert ${ }^{23}$ have shown the slips why such position is no longer sustainable, it is important to therefore revise Odù Ògúndá Otura too for a finer perspective. The revision of Orúnmilà's injunction on non-human animals in traditional Yorùbá philosophy is imperative because "in this respect, the old phraseology is at variance with the psychology of modern civilizations. This change in psychology is largely due to science, and is one of the chief ways in which the advance of science has weakened the hold of the old religious forms of expression." 24

With the foregoing preliminary statements, we now state in clear terms, our counterarguments against the justification in Odì Ògúndá Otura. From the Biological parlance, we glean that non-human animals can live fairly well without humans but the converse of this proposition cannot hold. In a related development, modern biology has also offered that non-human animals are the progenitors of humans through the process of evolution by natural selection. ${ }^{25}$ These revelations though implied in the Yorùbá creation story are usually depreciated even when they are crucial for revising Orúnmilà's sanction in Odù Ògúndá Otura. Let us explore the creation story to justify the biological locus that non-human animals can live even without humans, the converse being impossible.

According to an oral tradition, Olódùmarè the Supreme Deity in Yorùbá belief, resided in heaven, and below was a watery surface. He then sent his right hand man, Obàtálá the god of purity or morality with a snail shell (or a napkin in other accounts) filled with loose earth, a hen (some traditions say it is a rooster) and a pigeon. ${ }^{26}$ While this attests to events before the advent of humans on the planet, it is clear that non-human animals do not depend on humans rather humans depend on not only them but also other biotic and abiotic factors. For instance, the 
same tradition buttresses further that Obàtálá poured out the sand while the hen and the pigeon spread it with their claws on the watery surface so that land appeared. A chameleon was then sent to inspect the work and it brought back a report to Olódùmarè that the earth was wide enough, Ilé-Ife or the place of spreading. ${ }^{27}$ The place where this took place thus became known as Ilé-Ife (or Ifẹ), which is for the Yorùbá, centre of creation from where humans, began their dispersal. Later, Obàtálá was sent back with Orúnmilà, another òrìsà, to equip the earth.

This creation story serves the biological evidence that before humans, there was nonhuman animal life on the planet. The story reveals the role played by non-human animals in the creation of a world that will soon be occupied by humans. Are we morally justified to admit non-human animals as nothing more than entities fit for human ends? Are we justified to treat with disdain, entities that assisted in the creation of the world? As provoking as the posers are, it needs to be stated that traditional Yorùbá theogony has some semblances with the one from some religious traditions of the world like Judaism, Christianity and Islam. ${ }^{28}$ By placing humans the last in the order of creation, as chronicled in their sacred texts the semblance needs no expatiation. This necessarily implies that all other things that will sustain humans (non-human animals inclusive) were in place. But even as these stories inform the belief and attitude of the Yorùbá, it lacks scientific basis. It is therefore important to engage with the scientific basis for our claim that: "non- human animals can live even without humans, the converse being impossible."

Development and research in biology from the time of Charles Darwin attest that nonhuman animals have been living millions of years before the emergence of Homo sapiens and served as the medium of the preservation and transmission of favourable variations leading to the Homo grade. ${ }^{29}$ This is in line with evolution's perspective that "...the organism does not live for itself. Its primary function is not even to reproduce other organism; it reproduces genes, and it serves as their temporary carrier." ${ }^{30}$ Edward Wilson's claim is more imposing when we recall, biologically speaking that the emergence of organisms was around 3.8 billion years ago whereas the evolution of the genus Homo, was not observed not until about 2.5 million years ago. ${ }^{31}$ While presenting his fact that Homo sapiens must have evolved from pre-existing animals, Israeli erudite personae Yuval Noah Harari chronicles:

"Homo sapiens, too, belong to a family. This banal fact used to be one of history's most closely guarded secrets. Homo sapiens long preferred to view itself as set apart from animals, an orphan bereft of family, lacking siblings or cousins, and most importantly, without parents. But that's just not the case. Like it or not, we are members of a large and particularly noisy family called the great apes. Our closest living relatives include chimpanzees, gorillas and orangutans. The chimpanzees are the closest. Just 6 million years ago, a single female ape had two daughters. One 
became the ancestor of all chimpanzees, the other is our own grandmother.",32

However, for the purpose of this study, it is important to elucidate that all modern day non-human animals and humans evolved from common ancestors instead of the erroneous and accentuated tendency to tinker that humans evolved from apes and monkeys. This distinction is crucial as Nanda and Worms attest:

"Saying that humans evolved from gorillas or chimpanzees suggest that humans are more evolved than these animals. However, no creature can be any more evolved than another. We can only imagine that we are more evolved if we believe that intellect or ability to alter the environment is the most important criterion of evolution. However, that is an extremely humancentered way of looking at biology. We could as easily say that producing the greatest number of related species or the greatest number of individuals is the best measure of evolution. If we were to take these criteria seriously, it would be clear that insects are far more 'evolved' than humans." 33

This human-centered way of looking at biology is redolent in Odù Ògúndá Otura. Òrúnmilà's injunction that non-human animals are fit only for human ends alone impresses that they exist simply for the sake of humanity. Immanuel Kant will later share Òrúnmilà's anthropocentric perspective too when he brings in the notion of consciousness to the discursive fray. For Kant, "so far as animals are concerned, we have no direct duties. Animals are not selfconscious and they are merely as a means to an end. That end is man." "34 But this outlook that non-human animals lack consciousness is no longer valid. In 2012, a group of renowned scientists proclaimed through The Cambridge Declaration on Consciousness that:

"[c]onvergent evidence indicates that non-human animals have the neuroanatomical, neurochemical, and neurophysiological substrates of conscious states along with the capacity to exhibit intentional behaviors. Consequently, the weight of evidence indicates that humans are not unique in possessing the neurological substrates that generate consciousness. Nonhuman animals, including all mammals and birds, and many other creatures, including octopuses, also possess these neurological substrates." 35

What is suggestive of the foregoing is that we cannot dismiss non-human animals as entities without consciousness fit for human ends. Regardless of the status quo, Rainer Ebert suggests that "...with a reasonable degree of certainty... at least mammals and birds have the capacity for phenomenal consciousness. On my view, that makes relevantly normal, developed members of these taxonomic classes intrinsically valuable subjects of experience whom it is no less seriously wrong to kill as it is to kill you or me, other things being equal." 36

With these findings, it is appropriate to ascertain that there will be no buy-back in Ifá propriety if non-human animals cease to 
exist or become extinct through poaching and/or use for sacrifice as validated by Òrúnmilà. Incidentally, it had been documented that "the extinction rate of species ranges from approximately 1,000 to 10,000 times higher than natural extinction rates." 37 Elsewhere we glean: "...if this trend continues, as many as 2 million species of plants and animals will be exterminated worldwide by the middle of the next century." "38 So is it not the case that for the interest in Ifá culture to be sustained, the interest in continuous existence of animals can be compromised? Is it not the case that if the interest of the former is pursued it will adversely affect the latter? Given this reality, what is to be done? We consider the other arm of the limit before engaging with a plausible framework.

In showing the limit of Odù Ògúndá Otura from the moral-legal angle, we commence with the role played by Es̀u to strengthen the anthropocentric ties redolent in the Odì. One must not wish away the corpulent role of informant played by Ès̀̀ that humans concede to be devoted toward Òrúnmilà. The species of the rat, fish and bird did not have the benefit of this information. This is played out in the innocence latent in the poser by the rat species: "What is baba akeyo (the great teacher) saying?" The rats obviously did not see the connection between the seemingly irrelevant request to become a devotee on the one hand and the burning challenge of childlessness on the other hand. The anthropocentric outlook of the Odì is exhibited given that only humans had prior knowledge to concede devotion to
Òrúnmilà but not any other non-human animal.

Firstly, it is the conviction of this research that no moral agent should be held responsible eternally because of an action borne out of ignorance or lack of adequate or prior information. The species of the rat, fish and bird, have been unfairly treated, given their lack of prior information which informed their reluctance to be devoted to Òrúnmilà. The scene where Òrúnmilà was angered because the rat species failed to recognize him and where the bird species defecated on him, though aimed to justifying the inferiority of non-human animals to humans is very weak one. We hypothesize that had they been given a similar 'help' by Es̀u, perhaps they would not have behaved so unruly to upset Òrúnmilà.

Furthermore, the species of animals that encountered Òrúnmilà's wrath no longer exist. Is it not morally blameworthy to bestow on a later generation the sins or misdeeds of their ancestors? The injunction of Òrúnmilà is a direct affront to the Yorùbá maxim: Iká t'obá șe l'ọba ń ge (It is only the offender that is punished by the authority). This brings us to the discourse on the proportionality between crime and punishment. Adebayo Aina has successfully demonstrated that the Western traditional punitive theories cannot handle the proportionality factor. He labours to show that traditional Yorùbá perspective takes cognizance of this lacuna. In his words:

The Yorùbá belief is that it is he who commits a crime that should be sanctioned. 
And, whoever commits a crime cannot escape no matter how long he hides. This strictly provokes the judicious imposition of punishment on criminal as a means of establishing responsibility for human conduct without any extraneous inclination. Even, after the criminal admits his wrongdoing and is punished for that he remains in the memories of the people as a wrongdoer. ${ }^{39}$

In a similar fashion, David Hume had tinkered on the proportionality factor in crime and punishment when he pens: "punishment, according to our conceptions, should bear some proportion to the offence. Why then eternal punishment for the temporary offences of so frail a creature as man?"40 Even when David Hume was preoccupied with diminishing the possibility of life before or after physical death, his bearing on punishment may still be used for the purpose of this study. It is therefore a grave moral and legal oversight for Òrúnmilà, not to have taken proportionality seriously before his injunction. His oversight is a direct erosion of the respectable, holistic and comprehensive Yorùbá culture which is in the words of Oladele Abiodun Balogun:

"...a composition of knowledge, beliefs, art, moral, religion, customs, politics, technology, law and other living capabilities acquired by the individual as an indigenous member of the Yoruba race. As with other aspects of the culture, the legal arm is undoubtedly important to the dynamism and vitality of the Yoruba culture as a whole." ${ }^{\prime 1}$
In this section, the biological and morallegal limitations of Òrúnmilà have been revealed. However, we are still faced with a crucial issue - Peoples' interest in culture will make them consult Ifá. And when divination recommends animal sacrifice, it must be observed. The interest in the existence of non-human animals is also crucial as the perspective that they are of no more worth other than for human ends is now a weak thesis. It is therefore important to patent a framework for this clash. This is hub of the next section.

\section{Òrúnmilà and the Status of Non-Human} Animals: Why Ethical Individualism Matters: What is ethical individualism? How does it assist toward a truce when the interest in culture clashes with the interests of non-human animals? How does ethical individualism initiate an improved rendition or revision of Òrúnmilà in Ògúndá Otura? These three questions will be the focus in the remainder of this study.

The main thrust of ethical individualism is to evince "who counts morally, why and how."42 In the words of the foremost proponent of this outlook, Kai Horsthemke, we glean that "ethical individualism is stimulated by the idea of a copiously branching network in which individuals interact and coexist and cooperate with other forms of life." 43 We discern right away that this theory takes cognizance of all forms of life. It is the case that there may be levels of gradation from simple to complex among these individual forms of life, ethical individualism however upholds that "these 
individuals resemble one another and differ from one another in multitudinous ways with the characteristics associated with one variety typically overlapping those associated with another variety."44 The main thrust of ethical individualism has to do with the unique identity and characterization of each organism but not the genus or species that they are commonly subsumed. To make this point clear, a little bit of elaboration is pertinent.

Ethical individualism does not discriminate organisms on the grounds of belonging to the class of mammals, reptiles or aves. This taxonomy, it needs to be mentioned, is a derivation of human intellectual willpower. Ethical individualism is focused principally on each unique and distinct organism. Kai Horsthemke makes this amplification more obvious:

"Ethical individualism is a view that is sensitive to particular characteristics and to the complex pattern of similarities and differences that exist between individuals, a complex web of identity, similarity and diversity. What matters, on this view, is the individual characteristics of organisms, and not the classes within which these organisms are commonly subsumed." $" 45$

If ethical individualism contends that each organism be accorded recognition outside their taxonomy, then equality enters the discursive fray. Ethical individualism holds that the idea of equality does not necessarily imply 'identity' in treatment and consideration but that it is compatible with the idea of diversity in treatment and consideration. ${ }^{46}$ It acknowledges that the (conceptual) distinction between 'moral agent' and 'moral recipient' may be morally significant and may be the basis for sanctioning differential treatment and consideration. Ethical individualism denies that morally relevant differences between agents and recipients are exclusively or primarily relevant to the question of moral status. It denies also that these differences sanction unequal treatment and consideration. ${ }^{47}$ Given the fact in the outlook that individuals are similar in several ways and also different in diverse ways, this does not make one organism more or less a being with higher interest over the other. In the attempt to see how non-human animals can benefit from this intellectual approach, from the framework of ethical individualism, it is important to make a distinction between basic and non-basic rights. This distinction was developed by Kai Horsthemke wherein he insists:

"All morally considerable individuals have the same basic rights, although their non-basic rights may differ. Second, basic rights are "basic" in the sense of being "irreducible" or "underived". That is, they are not reducible to or based on duties, obligations, responsibilities etc., as they would be in duty-based theoriesinsofar as these theories permit talk of rights. Basic rights generate duties, responsibilities, non-rights, and indeed other rights. These rights, then, will be "nonbasic", in the sense of being "derived", or dependent on basic rights. They are instances of "core rights". Non-basic or derivative rights, it should be noted, are not 
generated by or derived from duties, obligations, responsibilities or non-rights. There exists an intimate relationship between non-basic rights and all of these but it is not one of direct derivation." 48

This intimate relation must not be seen from the anthropocentric perspective. There is therefore no synchrony between the basic and non-basic rights of non-human animals when their lives are cut short for human ends interminably as endorsed by Ifá tradition. Unfortunately, for non-human animals, "it matters only that they are not made to suffer and that their lives are not cut short for reasons that have very little, if anything, to do with them, their own wellbeing and interests." $" 49$ This truth is even made more appalling by the inference that "as far as animals are concerned, we are not different races and different cultures. We are one race; one culture; one oppressor; one bully; one killer." 50

From the foregoing, it is clear that the distinction between the killer and the killed is now vague. This is the inner kernel of ethical individualism. So, what happens when the interests of Ifá 'devotees' clash with the interests of non-human animals? We deduce from ethical individualism that the sacrifice made by the devotee using animals is an injury against life and everything that it represents. This is owing to the understanding in ethical individualism that all organisms even when they exhibit similarities and variations are unique in their own distinct way. Hence, the life of a human on this view is equal to the life of a tilapia.
However, for these 'non-devotees' of Òrúnmilà - we are fellow occupants of the planet, "...one culture; one oppressor; one bully; one killer." ${ }^{, 51}$ It is precisely for this reason that ethical individualism cautions and demands for a revision of the verdict or injunction in Odù Òúndá Otura as it is no longer tenable in contemporaneous times.

We have been able to establish that for nonhuman animals, they are as unique as humans albeit with a lower gradation but this does not vitiate their equality and basic rights. We also recognize that sacrifice in Ifá propriety when recommended by divination must be observed. However, a pivot achievement of ethical individualism is the repudiation of the anthropocentric and hegemonic outlook in Ògúndá Otura. It cautions and counters the outlook that nonhuman animals exist merely as irari (i.e. buy back) for human challenges. With ethical individualism, we may then demand that "the state or animal rights groups might negotiate with members of a culture, say, to integrate stunning into their slaughter practice, so that, while there would still be animal killing, suffering would at least be minimized." 52

Another course of action could be to bring to the knowledge of humans, (or shall we say 'devotees'?) the archaic outlook in Ògúndá Otura, and then start exploring other aspects of sacrifice that will reduce the shedding of blood of non-human animals. It is clear that an easy resolution will still be far off. One can only start negotiating because of the difficulty in transgressing established 
traditions and the gradual awareness that non-human animals too are beings with "interests that should not be cavalierly frustrated." 53 It is the strain in arriving at an outright resolution that informed Thaddeus Metz's conviction that his "aim is not so much to resolve the conflict between our duties to animals and our rights to culture, but rather to understand it, precisely as one that is extremely hard to resolve for involving comparably strong considerations that, despite their common moral foundation, pull in different directions." 54

Conclusion: The entirety of this intellectual graft seems to have attained two agenda. First, it disinters that the injunction by Òrúnmilà in Ògúndá Otura that non-human animals are for human end simplicter, is no longer tenable in the light of revelations from Biology and Moral Philosophy. Indeed, it needs no elaboration that "the old phraseology is at variance with the psychology of modern civilizations." Furthermore, we already showed that Òrúnmilà's injunction lacks biological, moral, logical and legal thrusts. Secondly, this study has also attempted to provide a context for resolution in ethical individualism that takes cognizance of peoples' interests in culture as well as the interests of non-human animals. It therefore calls for negotiation when the interest of the one intersects with the interest of the other, pending when the consciousness and awareness that non-human animals are nothing but irarí (buy back) gradually becomes a widespread and accentuated perception among Ifá adherents.
Author Contribution: The idea that evolved into this research was 'prehended' and codified by the author.

Conflict of Interest: There is no conflict of interest.

Acknowledgements: I wish to acknowledge the thought-provoking comments provided for the initial draft of this research by Ademola Kazeem Fayemi (Ph.D.), Department of Philosophy, University of Lagos, Nigeria. Without the colossal time and effort provided by 'Booda Kaso,' this essay will not have evolved into the present state. I am eternally grateful sir! In addition, the effort and constructive criticisms from Professor Helen Lauer, Department of Philosophy, University of Dar es Salaam, Tanzania were very helpful toward the evolution of the initial draft of this essay to its present state.

\section{References}

${ }^{1}$ Thaddeus Metz. "Duties Toward Animals versus Rights to Culture: An African Approach to the Conflict in Terms of Communion." In L. Cordeiro-Rodrigues \& L. Mitchell (eds.). Animals, Race and Multiculturalism. (London: Palgrave Macmillan 2017), p. 269.

${ }^{2}$ Alfred N. Whitehead. Science and the Modern World. (New York: Pelican Mentor Books 1948), p. 186

${ }^{3}$ Arthur L. Caplan. "Beastly Conduct: Ethical Issues in Animal Experimentation." The Ethical Dimensions of the Biological Science. (Cambridge: Cambridge University Press 1996), p. 183

${ }^{4}$ Op. Cit., Whitehead., p. 184

${ }^{5}$ E.M. Lijadu. Ifá, Imole Re Ti Ise Ipinle Isin Ni Ile Yorùbá. (Exeter: James Townsend \& Sons 1923), p. 1 
${ }^{6}$ William R. Bascom. Ifá Divination: Communication between Gods and Men in West Africa. (Indiana: Indiana University Press 1969), p. 14

${ }^{7}$ Nicholaj M. Frisvold. Ifá: A Forest of Mystery. (Paris: Bibliotheque Rouge 2016), p. 13

${ }^{8}$ Kazeem D. Fayemi. "Human Personality and the Yoruba Worldview: An Ethico-Sociological Interpretation." Africology: The Journal of Pan African Studies. 2009 Vol. 2 (9): 166-76.

${ }^{9}$ Oladele O. Balogun \& Kazeem D. Fayemi. "The Relevance of Ifá to Jurisprudence and Human Rights Discourse." (The International Conference on Philosophy and the Law in Africa 2008), p. 37

${ }^{10}$ Kola Abimbola. Yorùbá Culture: A Philosophical Approach. (Birmingham: Iroko Academic Publishers 2006), p. 119

${ }^{11}$ Ola Longe. Ifá Divination and Computer Science: An Inaugural Lecture. Delivered at the University of Ibadan on Thursday, 22 December, 1983. (Ibadan: W. Giradet Press (W.A) Co. 1998), p. 15

${ }^{12}$ Bolaji Idowu. Olódùmarè: God in Yorùbá Belief. (London: Longmans 1962)

${ }^{13}$ See Daniel O. Epega. Iwe Ifá ati Itumo Ala. (Lagos: The Hope Rising Press 1931), p. 15 \& Wande Abimbola. Ijinle Ohun Enu Ifá. (Ibadan: Oxford University Press 1969)

${ }^{14}$ Olufemi Taiwo. "Ifá: An Account of a Divination System and Some Concluding Epistemological Questions." In Kwasi Wiredu (Ed.). $A$ Companion to African Philosophy. (New York: Blackwell 2004), pp. 305-6

${ }^{15}$ Áwo Fáladé Òsúntólá. "Is Animal Sacrifice Important." 2013. Available at http://iyaifagbemi.blogspot.com.ng/2013/03/isanimal-sacrifice-important.html?m=1. Accessed on 12 January, 2018

${ }^{16}$ Ibid

${ }^{17}$ Ebun Oduwole \& Kazeem Ademola Fayemi. "Animal Rights vs. Animal Care Ethics: Interrogating the Relationship to Non-Human Animals in Yoruba Culture." In J. Chimakonam (Ed). African Philosophy and Environmental Conservation. (London: Routledge 2018), p. 77

${ }^{18}$ Immanuel Kant. Lectures on Ethics. (New York: Harper \& Row. 1963)

${ }^{19}$ Peter Singer. Animal Liberation: A New Ethic for Our Treatment of Animals. (New York: Avon Books 1975); Peter Singer. "Not for Humans Alone: The Place of Nonhumans in Environmental Issues". ETHICS: Thought and Practice. (New Jersey: Prentice-Hall Inc.1985)
${ }^{20}$ Tom Regan. The Case for Animal Rights. (Berkeley: University of California Press 2004)

${ }^{21}$ Joel Feinberg. "The Rights of Animals and Unborn Generations." ETHICS: Thought and Practice. (New Jersey: Prentice-Hall Inc. 1985)

${ }^{22}$ Arthur L. Caplan. "Beastly Conduct: Ethical Issues in Animal Experimentation." The Ethical Dimensions of the Biological Science. (Cambridge: Cambridge University Press 1995)

${ }^{23}$ Rainer Ebert. The Wrongness of Killing. Unpublished PhD Thesis. Rice University. 2016

${ }^{24} \mathrm{Op}$. Cit., Whitehead, p. 191

${ }^{25}$ Charles L. Darwin. On the Origin of Species by means of Natural Selection, or the Preservation of Favoured Races in the Struggle for Life. (New York: Modern Library Edition 1949)

${ }^{26}$ See Op. Cit., Idowu, pp. 18-21; O. Awolalu. Yoruba Beliefs and Sacrificial Rites. (Essex: Longman 1979)

${ }^{27}$ Funmi Olojede. "The Exodus and Identity Formation in View of the Yoruba Origin and Migration Narratives." Scriptura. 2011, 108 p.343

${ }^{28}$ See Genesis 1: 28 and Al-Qur'an 2:47.

${ }^{29}$ Edward O. Wilson. Sociobiology: The Abridged Edition. (London: Belknap Press 1998), p. 3

${ }^{30}$ Ibid., p. 3

${ }^{31}$ Yuval N. Harari. Sapiens: A Brief History of Humankind. (Canada: Random House 2014), p. 7

${ }^{32}$ Ibid., p. 11

${ }^{33}$ S. Nanda \& R.L. Warms. Cultural Anthropology. (California: Wadsworth 2010), p. 7

${ }^{34}$ Op. Cit., Kant, p. 239

${ }^{35}$ The Cambridge Declaration on Consciousness (Cambridge, July 7, 2012) Available at http://fcmconference.org/img/CambridgeDeclara tionOnConsciousness.pdf Retrieved on $1^{\text {st }}$ April, 2018.

${ }^{36}$ Op Cit., Ebert, p. 212

${ }^{37}$ R.S. Keller \& O.E. Wilson. The Biophilia Hypothesis. (Washington: Island Press 1993)

${ }^{38}$ S.L. Pimm, G.J. Russell, J.L. Gittleman, T.M. Brooks. "The Future of Biodiversity." Science. 1995 (269) pp. 347-50.

${ }^{39}$ Aina A. Adebayo. "Crime, Punishment and the Proportionality Factor in Contemporary Society: The Yorùbá Experience." Philosophia Africana. 201618 (1) p. 16

${ }^{40}$ David Hume. An Enquiry Concerning Human Understanding. Edited and with an introduction by Peter Millican (Edinburgh: Edinburgh University Press 2007), p. 149 
${ }^{41}$ Oladele O. Balogun. "A Philosophical Defense of Punishment in Traditional African Legal Culture: The Yoruba Example." Africology: The Journal of Pan African Studies. 2009 3(3) p. 44

${ }^{42}$ Kai Horsthemke. "Animals and the Challenges of Ethnocentrism.” In L. Cordeiro-Rodrigues \& L. Mitchell (eds.). Animals, Race and Multiculturalism. (London: Palgrave Macmillan 2017)

${ }^{43}$ Ibid., p. 141

${ }^{44}$ Ibid., p. 141

${ }^{45}$ Ibid., 141

${ }^{46}$ Ibid., p. 142

${ }^{47}$ Ibid., p. 143

${ }^{48}$ Kai Horthemske. The Moral Status and Rights of Animals. (Pinegowrie: Porcupine Press 2010)

${ }^{49}$ Op Cit., Horthemske 2017, p. 142

${ }^{50} \mathrm{G}$. Francione. "The Abolitionist Approach to Animal Rights." Available at https://www.facebook.com/abolitionistapproach/ posts/530170923669333 Retrieved on 2nd April, 2018

${ }^{51}$ Ibid

${ }^{52}$ F. Zuolo. "The Priority of Suffering Over Life: How to Accommodate Animal Welfare and Religious Slaughter.” The Ethics Forum. 2014 (9), p. 180

${ }^{53} \mathrm{Op}$ Cit., Caplan, p. 183

${ }^{54}$ Op Cit., Metz, p. 292

${ }^{55}$ Op Cit., Whitehead, p. 191 